
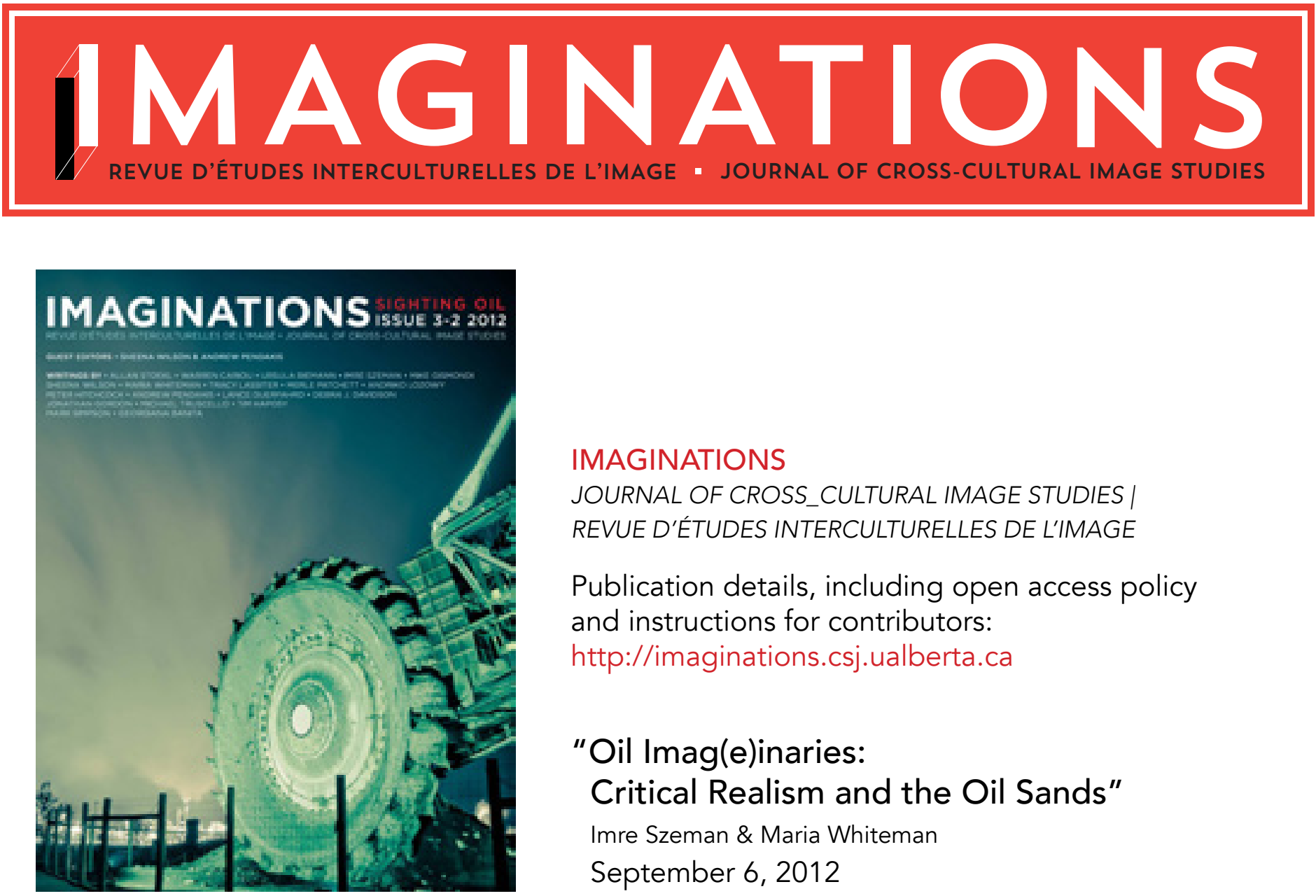

\author{
IMAGINATIONS \\ JOURNAL OF CROSS_CULTURAL IMAGE STUDIES | \\ REVUE D'ÉTUDES INTERCULTURELLES DE L'IMAGE \\ Publication details, including open access policy \\ and instructions for contributors: \\ http://imaginations.csj.ualberta.ca
}

\title{
"Oil Imag(e)inaries:
}

Critical Realism and the Oil Sands"

Imre Szeman \& Maria Whiteman

September 6, 2012

To Cite this Article:

Szeman, Imre and Maria Whiteman. "Oil Imag(e)inaries: Critical Realism and the Oil Sands" Imaginations 3:2 (2012): Web (date accessed) 46-67. DOI: 10.17742/IMAGE. sightoil.3-2.5

\section{To Link to this article:}

http://dx.doi.org/10.17742/IMAGE.sightoil.3-2.5

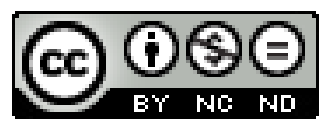

The copyright for each article belongs to the author and has been published in this journal under a Creative Commons Attribution NonCommercial NoDerivatives 3.0 license that allows others to share for non-commercial purposes the work with an acknowledgement of the work's authorship and initial publication in this journal. The content of this article represents the author's original work and any third-party content, either image or text, has been included under the Fair Dealing exception in the Canadian Copyright Act, or the author has provided the required publication permissions. 


\section{OIL IMAG(E)INARIES: CRITICAL REALISM AND THE OIL SANDS IMRE SZEMAN AND MARIA WHITEMAN}

This photo-essay constitutes an initial attempt to map out the forces and dynamics of capital at work in Fort McMurray, Alberta-a primary site of global oil extraction and a space that is now at the heart of the contemporary Canadian economy; it does so through the practice of 'critical realism' advocated by artist and critic Allan Sekula. The essay consists of three parts. In the first part, we describe the characteristics of Sekula's critical realism, focusing in particular on his employment of this aesthetico-political practice in his book Fish Story (1991), an attempt to challenge dominant narratives about globalization as immaterial and unrepresentable by means of a focus on the transportation of goods by container ships. In the second part, we explore the challenge of representing another all-too frequently hidden material dimension of globalization: our continued dependence on oil and its by-products. Instead of focusing directly and literally on the site of oil extraction, the photo-essay we produce in the third part probes the effects of oil on life and labour in Fort McMurray. We do so in order to better understand the city's specific socio-political challenges and to grasp the broader implications of oil for contemporary politics, culture and representation.
Ce photoreportage constitue une première tentative de mettre en image le pouvoir et la dynamique du capital à Fort McMurray, en Alberta, où se trouve le site principal d'extraction pétrolière qui est au cœur de l'économie contemporaine canadienne. L'approche que nous proposons à cette fin est celle du « réalisme critique » mis de l'avant par l'artiste et critique Allan Sekula. L'article se divise en deux parties. Premièrement, nous décrivons les caractéristiques du réalisme critique de Sekula en mettant l'accent sur son emploi de la pratique éstheticopolitique dans son livre Fish Story (1991); ce dernier renverse les discours dominants de la globalisation perçue comme processus immatériel irreprésentable en se concentrant sur le transport des produits commerciaux sur les bateaux porte-conteneurs. Deuxièmement, nous tentons de présenter une autre dimension matérielle méconnue de la globalisation : notre dépendance vis-àvis du pétrole et de ses sous-produits. Au lieu de mettre le site d'extraction au premier plan, notre photoreportage se concentre sur les effets du pétrole sur la vie et sur le travail à Fort McMurray afin de mieux comprendre les défis socio-politiques de la ville et les implications au sens plus large du pétrole sur la politique, la culture et les représentations contemporaines. 


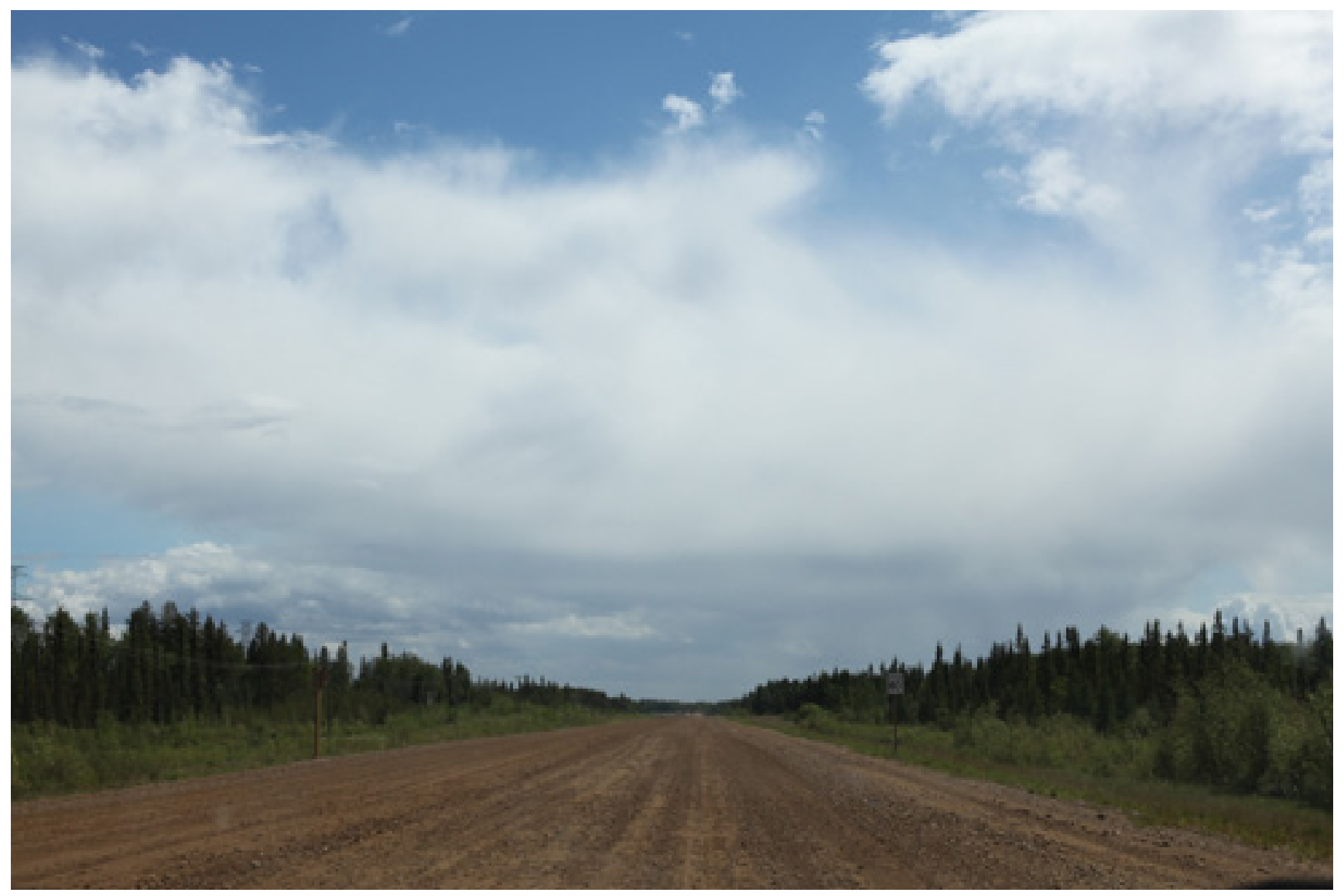

Fig. 1 Maria Whiteman, HWY 63 N \#3

Nothing is indeed quite so perverse or aberrant for the truly postmodern person as the polemic expression 'photographic realism'-as though photography, today so mysterious and contradictory an experience, had anything reassuringly trustworthy or reliable about it. (Jameson, "Modernism” 53)

In what ways might it be possible to more fully explain the social and economic dynamics at work in the Alberta oil sands? This essay constitutes the beginning stages of an aesthetico-theoretical experiment, undertaken jointly by an academic and an artist, whose aim is to map the forces at work in Fort McMurray, Alberta, through the combined use of text and images. The way in which we frame our approach is through the employment of a critical realism that attempts to uncover the forms and shapes of life in late capitalism in a manner that is analytically rich and nuanced. We take the term "critical realism" from the work of photographer and theorist Allan Sekula, whose photo-series and book Fish Story remains (to our minds) unduly neglected as an aesthetic project whose intent is precisely that of navigating the complexities of global capital and to do so in a manner that might engender new political possibilities. ${ }^{1}$ 
The thought that any kind of realism-much less a realism indebted to the necessarily troubled relationship of photography to the real-might be open to the task of naming the operations of twenty-first century global capitalism might, for many critics and scholars, be seen as misguided and misplaced. After the criticisms of the Frankfurt School and Bertolt Brecht of the literary theories of György Lukács, and Fredric Jameson's description of the relation of different generic forms to specific historical periods, the affirmation of an untroubled political function for realism today seems to constitute a willful misunderstanding of the operations and possibilities of genre. ${ }^{2}$ Sekula's version of realism is not one that relies uncritically on the relation of the photographic image to some easily accessible real that can be comprehended outside of the discursive and narrative frames that constitute the social. At the same time, Sekula resists the all-too easy dismissal of the possibilities of the photographic image-its almost unprecedented capacity to provoke conceptual, theoretical and political openings as a result of its relation to the real. Our visual-textual experiment proceeds in three parts. First, we offer an overview of Sekula's account of critical realism in order to address some of the potential anxieties that attend the link of photography with realism, as well as to explore and explain the manner in which he assembles phototexts that address aspects of operations of global capital that would otherwise remain hidden or obscured. Second, we briefly explore the specific difficulties of capturing our subject matter in photographs, in order to shape the focus of our critical-visual practice with respect to the oil sands. Finally, we experiment with a mapping of a specific, essential aspect of capitalism-its dependence on oil as dominant energy source-by means of a critical-realist photo-essay of Northern Alberta oil, specifically the city of Fort McMurray located at the heart of Canada's controversial oil sands development.

In Postmodernism, or, The Cultural Logic of Late Capitalism, Fredric Jameson writes:

An aesthetic of cognitive mapping-a pedagogical political culture which seeks to endow the individual subject with some new heightened sense of its place in the global system-will necessarily have to respect this now enormously complex representational dialectic and invent radically new forms in order to do it justice. This is not then, clearly, a call for a return to some older kind of machinery, some older and more transparent national space, or some more traditional and reassuring perspectival or mimetic enclave: the new political art (if it is possible at all) will have to hold to the truth of Postmodernism, that is to say, to its fundamental object-the world space of multinational capital —at the same time at which it achieves a breakthrough to some as yet unimaginable new mode of representing this last, in which we may again begin to grasp our positioning as individual and collective subjects and regain a capacity to act and struggle which is at present neutralized by our spatial as well as our social confusion. (54)

The short critical-realist photo-essay found in the third part of this essay is by no means an example of that "unimaginable new mode of representing" that Jameson names in his famous description of cognitive mapping (2003). At a minimum, however, we hope to show that (contra Jameson's claim in the epigraph) photographic realism can operate in a mode other than in the direct one-to-one relation between image and object/event. This essay is in part about how photos can contribute to a cognitive mapping of a resource reality about which we too commonly imagine we already know everything there is to know.

\section{On Critical Realism: Photography and Capitalism}

The exhibit and book that make up Sekula's Fish Story are framed in explicit opposition to what had by the mid-1990s become the dominant way of understanding globalization-as comprised by the immaterial flows of media images, economics, politics and ideology across now anachronistic national borders. Fish Story is an appropriate title for the project, the third in a series of projects that explore "the imaginary and material geographies of the advanced capitalist world" (202). Sekula's photographs, the accompanying text, and the long essay that breaks up the book, explore the central and continued importance of shipping and the sea in our attempt to make sense of the present. It does so in 
order to counteract what Sekula sees as the hyperbolic 'fish story' of globalization, as it has been developed both in academic accounts and in the popular press, which stresses the easy movement of culture and money across borders at the expense of the materiality of global labour and the physical goods moved around the world via the world's oceans. Sekula writes:

My argument here runs against the commonly held view that the computer and telecommunications are the sole engines of the third industrial revolution. In effect, I am arguing for the continued importance of maritime space in order to counter the exaggerated importance attached to that largely metaphysical construct, "cyberspace," and the corollary myth of "instantaneous" contact between distance spaces... In the imagination, e-mail and airmail come to bracket the totality of global movement, with the airplane taking care of everything that is heavy. Thus the proliferation of air-courier companies and mailorder catalogs serving the professional, domestic, and leisure needs of the managerial and intellectual classes does nothing to bring consciousness down to earth, or to turn it in the direction of the sea, the forgotten space. (50)

Sekula's photographic project undertakes the challenge of presenting a material history of globalization. In contrast to those attempts to theorize global space that take as given a description of the world as dominated primarily by the chaotic flow of disembodied signsystems-whether this is seen as the transnational flow of money or of culture-in both text and images Sekula traces out the concrete labour and material networks that produce and are produced by globalization. The aim is not to deny the existence and importance of communication technologies and their effect in collapsing the globe spatially, nor to contest the fact that capitalist space is being fundamentally reorganized. Rather, he wishes both to complicate the picture and to restore to the study of global capitalism a number of factors that are in danger of fading away from our contemporary picture of the globe. For example, the focus on the harbour, the site where "material goods appear in bulk" (12), allows Sekula to emphasize the ways in which the globe resists being turned into a one big village. He writes:

Large-scale material flows remain intractable. Acceleration is not absolute: the hydrodynamics of large-capacity hulls and the power output of the diesel engines set a limit to the speed of cargo ships not far beyond that of the first quarter of this century. It still takes about eight days to cross the Atlantic and about twelve to cross the Pacific. A society of accelerated flows is also in certain key aspects a society of deliberately slow movement. (50)

Sekula's emphasis on the materiality of globalization might seem to be merely the result of a photographic imperative or limit: the need to focus on and capture visible signs. And of course, one of the problems that the global present has posed for contemporary art, especially art that is politically committed, is that the reality of the world system is something that seems altogether impossible to represent. The complicated web or network of technological and social systems that make-up contemporary global finance or mass media, for example, defies the ability of our contemporary aesthetic forms (all of which had their genesis prior to the twentieth century) to render them in some way comprehensible, due both to their scale and their invisibility-powerful electronic phantoms (in the case of financial and media transactions) whose presence everywhere and at all times makes them no easier to frame in snap shot of any given place, event or thing. So what does Sekula propose to do that is different, that makes comprehensible what seems incomprehensible?

As Benjamin Buchloh points out, the avant-garde in photography has since the 1950s become identified primarily with modernist experimental forms such as photomontage, while documentary photography, with its insistence on capturing the 'real,' has been marginalized as an artistic practice. This is because the relationship of the photograph to reality has been viewed with increasing suspicion over time, especially in terms of the political potential of photography. Once seen as the 
unique characteristic of photography, it is now common to view the 'Real' of the photograph as that which most obscures or interrupts the procedures by which 'reality' in the photograph is managed and constructed (thus its 'perversity' or 'aberrance' for the truly postmodern person). So while critical photographic practices have turned away from the use of photography to document reality, for Sekula it is in fact the photograph's unavoidable "social referentially, its way of describingalbeit in enigmatic, misleading, reductive and superficial terms-a world of social institutions, gestures, manners, relationships" (Sekula, Photographs ix) that makes it a necessary tool in the attempt to understand the present. ${ }^{3}$ In opposition to both the interdiction on representing the real in the aesthetic practices of the Left within which Sekula positions himself, as well as the various critical and artistic suspicions about documentary photography, his photographic practice insists on the importance of addressing reality. This is a form of realism that does not settle for the quotidian surfaces and experiences that are usually imagined (especially in relation to the photographic images) as reality, but a realism whose aim is to document what is hidden in that phenomenal everydayness and its ready-to-hand socio-political codes and narrative conventions that are all-too easily passed off as reality. In Fish Story, this is the world of industrial labour and the concrete movement of goods that are hidden or obscured by most discourses concerning globalization, whose representation thus gives us a different vision of the global than that produced in either its victorious or resistant modalities.

It is important to emphasize that the realism of Sekula's photographs is not a naïve realism that insists that the structure of the contemporary world is visible and accessible to simple photographic representation. Instead, Sekula's aim has been to create a "critical realism." Sekula characterizes this as

a realism not of social facts but of everyday experience in and against the grip of advanced capitalism. This realism sought to brush traditional realism against the grain. Against the photo-essayistic promise of 'life' caught by the camera, I sought to work within a world already replete with signs. $(\mathrm{x})$
It is an essential aspect of Sekula's 'critical realism' that the photographs must both insist on their relationship with reality while simultaneously drawing attention to the fact that they are partial and constructed, without either position canceling the other one out; the reality in the photographs is further not merely indexical-an accumulation of details about the external world-but reveals and critiques the system of social, political, and economic relationship under capitalism. This dialectic between what Buchloh calls "a conception of photography as contextual (i.e., as a discursively and institutionally determined fiction) and a conception of photography as referential (i.e., as an actual record of complex material conditions)" is maintained by Sekula through three procedures (195). First, Sekula's photographs are not random snapshots, but are arranged in a narrative sequence. The indexical function of individual photographs is problematized by their inclusion in a narrative that has necessarily been created rather than offered up by reality. Second, since the photographs exhibit a wide range of techniques, photographic conventions and aesthetic choices, the different ways of producing the real are highlighted formally. Finally, as Buchloh notes, "the sudden focus on a seemingly irrelevant and banal detail interrupts the overall narrative in the manner of a Brechtian intervention that reminds the viewers/readers of the constructed nature of the representation with which they are confronted" (196).

In assessing the operations of critical realism, it is important to actually look at Sekula's photographs themselves, however briefly, in order to assess its possibilities and limits as a way of analyzing the space of global culture. Fish Story is comprised of seven narrative sequences of photographs interspersed with short pieces of text that add additional information to the reading of the narrative, either in the form of anecdotes or historical or social information. The book also includes an essay in two parts entitled "Dismal Science" (41-55; 105-38) that traces with great complexity the historical shift in representations of the sea, from the maritime panoramas of seventeenth-century Dutch painting to the development of containerized shipping in the 1950s and 
1960s, and from an ocean sublime in its sheer breadth and scale to one entirely rationalized by the logic of containment: the container hides its cargo, transforming its concrete contents into abstract units that, stacked up, even resemble money. To capture the full complexity of Sekula's project, the multiple narratives that exist within Fish Story - the seven photographic narratives themselves, the accompany text, and the essay-must themselves be read as a larger, heterogeneous and ambiguous narrative about globalization that remains indeterminate, even though Sekula adheres to a vision of globalization that emphasizes the importance of the economic within it.

We will limit ourselves here to a consideration of two of Sekula's photographic narratives in Fish Story. The photographs in the very first section of the book are of the harbours of California-the forgotten harbours of L.A., Long Beach and San Diego, which nevertheless are amongst the busiest in the United States. Sekula begins his study of harbours and of the sea at home, before traveling outward to other ports-Gdansk, Rotterdam, Ulsan in South Korea, Vigo in Spain, and Veracruz, Mexico. As the text that begins this first narrative sequence reveals, however, with respect to the sea, home has become a problematic concept. There are, strictly speaking, no American shipping vessels: ships travel under flags of convenience that have made the Bahamas and the Marshall Islands into world shipping powers, while simultaneously transforming the concept of the nation into little more than a commodity to be bought and sold. Nevertheless, at the 'local' site of the Los Angeles harbour, where materially the United States encounters the East that lies to the West of it, a whole host of relations becomes apparent through the sequence of individual photographs that Sekula takes: the end of the ship-building industry in the United States and its continuation; the transformation of harbour into a space of "bourgeois reverie on the mercantilist past" (12); the ecological catastrophes visited on the globe as a result of the demands of a fuel-hungry economy; the appropriation of the sea as an architectural motif in the design of the conference room of an advertising agency; the decidedly less romanticized, rationalized world of a contemporary container facility that has rendered the sea into a giant factory; a sign of race, as World War II-era housing for shipyard workers is moved from its now desirable location next to the sea to by re-used in South-Central Los Angeles; the co-existence of low technology with high technology; the militarization of the sea; and the effects of technological 'progress' on individual lives. This sequence of photographs, outlining the multiple modalities of shipping and the work of harbours, is followed by text that recounts an odd moment in geo-political history: "Weapons for the Iraqis in the forward hold. Weapons for the Iranians in the aft hold. For a moment the global supply network is comically localized, as pictorially condensed as a good political cartoon" (32).

The second photographic narrative concerns Ulsan, the factory town built by Hyundai in order to serve the largest shipyard in the world. Here, we see a contemporary version of Utopia coming to completion (the ship Hyundai Utopia in a shipyard), followed by the myths of its primordial origin (a picture of the ironclad turtle-ship used in defeat of Japan in 1592 in the Hyundai headquarters); the laboring body, displaced from the fishing village that once occupied the site of the shipyards and from the former site of industrial labour in the West, set against the profits extracted from it (a photo of an executive golf course on the edge of the shipyard); a billboard announcing plans for an amusement park set against an image of the fishing village that it will displace. Against these images of Ulsan, it is important to weigh Sekula's anecdote about the "The Korean's Workers' Museum" established by an American crew on one of the first ships built by Daewoo, another of Korea's shipbuilding giants:

When an American crew picked up the first of these ships from the Daewoo dockyard, completed the sea trials, and began the voyage across the Pacific, they discovered in the nooks and crannies of the new ship a curious inventory of discarded tools used in the building of the vessel: crude hammers made by welding a heavy bold onto the end of a length of pipe, wrenches cut roughly from scraps of deck 
plate. Awed by evidence of an improvisatory iron-age approach to ship building, which correspond to their earlier impressions of the often-lethal brutality of Korean industrial methods, they gathered the tools into a small display in the crew's lounge, christening it "The Korean Worker' Museum."

American elites have cultivated a fantastic fear of superior Asian intelligence; in doing so they obscure their own continued cleverness. (74)

It is perhaps hard to get a sense of Sekula's entire project from these brief descriptions of his photos and a summary of small portions of his text. Nevertheless, it allows us to suggest what we see in this effort to map global space and to do it in a 'concrete' or material way rather than from a large-scale assumption that culture is deterritorialized in the way imagined by some critics and transnational corporations, and to engage in this mapping through photography - a medium whose ability to relate to the concrete has been rendered increasingly suspect in critical thought. Sekula's photographs and text together produce a vision of the global present that is just as complex as one that a critic such as Arjun Appadurai wishes to produce via his vocabulary of 'scapes' (to point to but one prominent example of a new discourse whose intent is to better grasp the complexities and contradictions of contemporary global reality). It is shot through with all of the numerous contradictions and paradoxes that globalization introduces: the displacement of labour; the wholesale transformation of societies; the complexities of race and identity; the growing abstraction of even the most apparently concrete processes; the existence of new localities, both those generated by capital and in resistance to it; the rationalization of production; and the continued existence of labour and the labouring body in a world that when viewed through the Western media sometimes seems to have commodity traders and economic forecasters as its only possible professions. It addresses these various levels in multiple ways: through direct documentation, through the juxtaposition of images with text, anecdotes with defamiliarizing photonarrative sequences, serious academic writing with offhanded comments, important images with apparently minor and trivial ones. By focusing on sea-trade as the axis along which to examine global phenomena, Sekula also manages to get beyond the nation into the 'space' of globalization, a space marked by the criss-crossing of ships not only from West to East, center and periphery, but within the periphery itself (Hong Kong to Tapei, Taipei to Shenzhen, Shenzhen to Beijing, and so on), thereby disorganizing this binary in a way that insists on a new conception of space. Nevertheless, Sekula's critical realism maps this space with new insights and a density of experience that is often missing from accounts of the framing forces and energies of globalization. The insistence of his photographs on recording the reality of specific sites, and furthermore, the multiplicity of signs in this reality, accomplishes three things. First, by focusing on labour, it draws into question a narrow academicism that has rendered globalization into a name for the global dispersal of cultural commodities. Second, by insisting on the visibility of globalization, Sekula's critical realism challenges us to avoid turning the circuits and spaces of globalization into something that, like Kant's sublime, is 'too big for representation.' Finally, by mapping the everyday spaces of labour that are all too often hidden from view, it encourages a renewed ethnographic attention to globalization, the reading of signs in and from reality, rather than as they have been transformed and rendered symptomatic in those global cultural commodities that cultural critics love to decode.

We do not mean to suggest that Sekula's attempt to reinvigorate the genre of realism is without its own problems (which would need to be investigated in more depth). Nevertheless, it is clear to us that Sekula's mode of critical realism opens up a way of thinking about the politics of globalization and of the globalization of culture that permits us to remain both open to and yet critical of the potentialities occasioned by the contemporary reorganization of space. Sekula's criticalaesthetic practice is a model of how it might be possible to think space-and so, too, culture and economicsdifferently, and one that avoids becoming, as much contemporary criticism all too quickly and all too frequently does, "indistinguishable from an ideological 


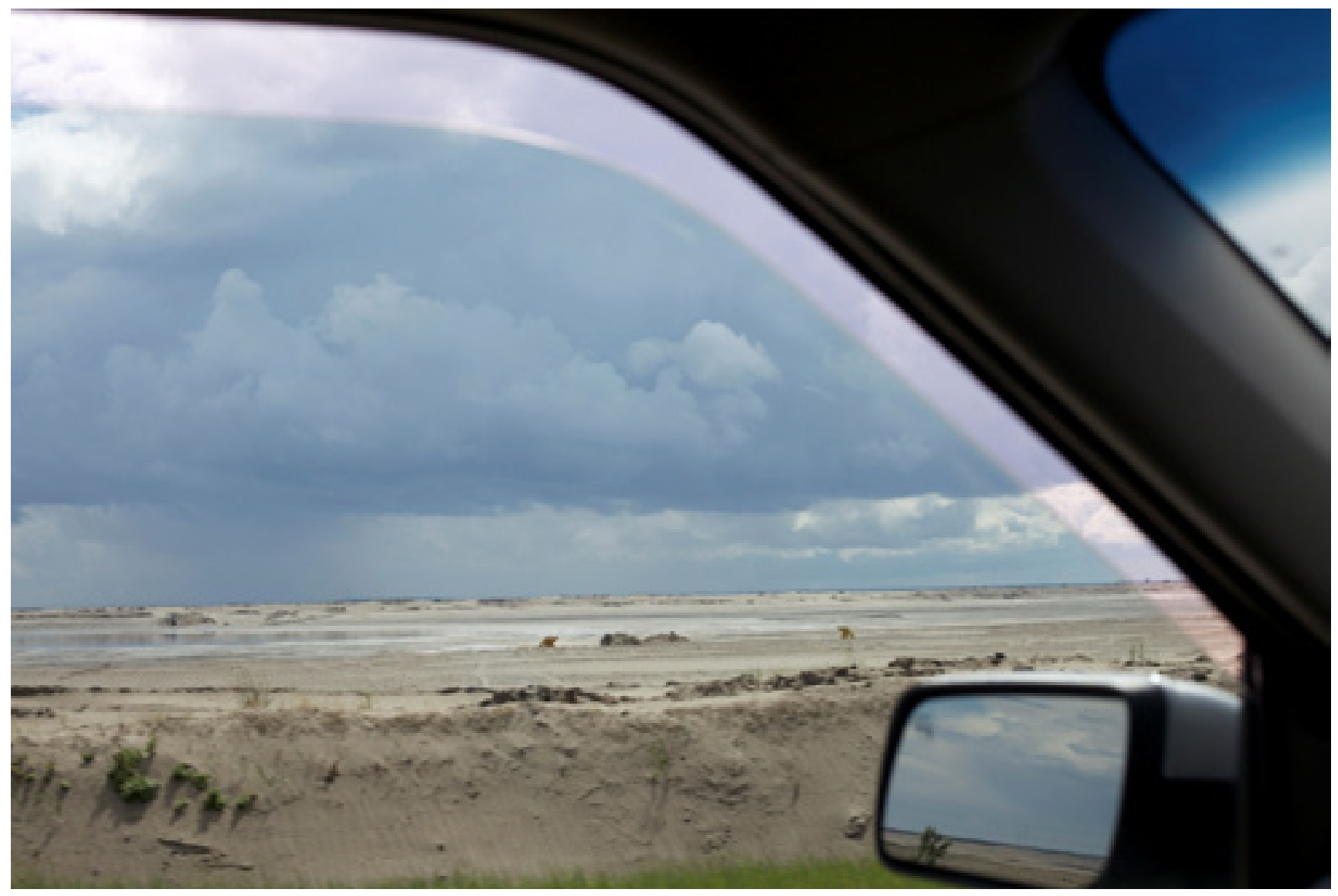

Fig. 2 Maria Whiteman, Dune

legitimation of the social forms that are the creation of global capitalism” (Dirlik, "Global” 36).

More than a strict model that should be taken as the framework for all future politically motivated aesthetic investigation, Sekula's critical realism highlights a means and method by which to name the materiality of a global system whose generative force all too often seems to have evaporated into the immateriality of communication systems and the effects of a hi-tech revolution. Against those who are anxious at the very thought of a 'capitalist realism'-anxious because the conjunction of the terms immediately suggests a theoretical limit, a too quick arrival at a solution, or a misunderstanding of realism as an easily-adopted interpretative pragmatism instead of a historical genre burdened by hermeneutic preconceptions-the analysis that we hope to provide here by means of a photo-essay of a key site of globalization in Canada is intended to challenge the comforts of incapacity that all too often attends the identification of global capital as an unrepresentable system. ${ }^{4}$

\section{Oil in the Streets?}

Such is the promise of critical photographic realism. To what effect might it be used in trying to name another 


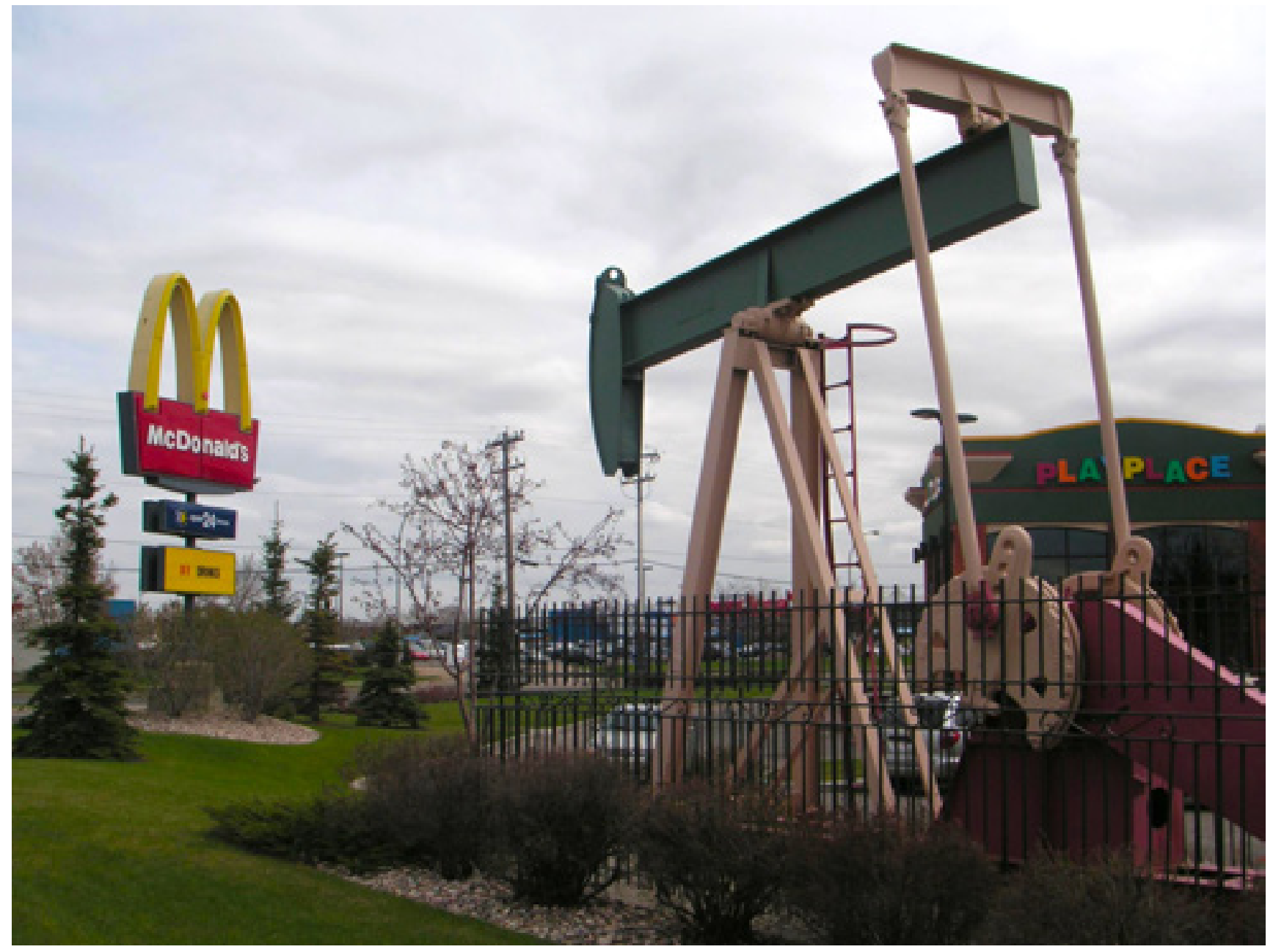

Fig. 3 Imre Szeman, Pumpjack

largely hidden dynamic of globalization: the system of oil extraction and production that is the lifeblood of capitalism-so essential to it that capitalism could not even exist in its absence? It is telling that even in the age of Apple and Google, any list of the largest companies on the planet is crowded with firms who generate the ultimate substance on which the planet's economy runs: oil.

It might seem questionable to start from the assumption that the realities of oil are hidden from view. But consider: even in the streets of Edmonton, a city whose economy has continued to grow as a result of the role it plays in servicing and supporting Canada's oil sands, there are fewer directly visible signs of oil than one might imagine. On the eastern edge of the city, a large stand of refineries and oil tanks sit just off the Anthony Henday freeway. Lit up like Christmas trees and smoldering away in the crystalline winter air of Edmonton, refinery row can be seen from almost any building in the city over a few stories high. But it is easy 
enough to resolve the aesthetic/environmental/economic problem these industrial objects pose: turn your eyes to the west or simply stay low to the ground. What does one then see? To the west: a sky animated by the beautiful sunsets that grace northern skies; low to the ground: banal commercial and residential streets, but also the deep, wooded valley of the North Saskatchewan River, as striking and attractive as any urban park anywhere in the world. There are many smaller signs marking the significance of oil to the making and shaping of this part of the world-a billboard advertising a strip club with the tag-line "We Support Big Oil!", a life-sized bronze statue of rig workers in the middle of West Edmonton Mall, a multi-coloured pumpjack in the parking lot of a suburban McDonald's-but none linger long in one's imagination. Instead of demanding an account of the what and the why of Canada's most northerly major city, they appear as the sort of curiosities one might expect to come across in the wild, wild West, and can be as quickly and easily written out of one's view as the much larger and more intimidating industrial structures from whence the lifeblood of petrosocieties flows.

One could object: is not the very existence of Edmonton a visible sign of oil culture? Are not its skyscrapers and that of its sister-city, Calgary, nothing if not oil rendered visible? Indeed, is not the whole of global modernity itself nothing but liquid oil transformed into the capacity for movement and solidified into objecthood? The problem of rendering the reality of oil visible in the form of a photo-essay like the one that Sekula produces in Fish Story is two-fold: either oil is so contained within the quotidian landscape of modernity that it does not present itself to view, or it is so omnipresent, equivalent to global capitalist modernity itself, that it is hidden in plain sight. Given this either/or, all or nothing, how is one to proceed?

To try to map oil imaginaries via images of oil produces an interpretive hermeneutic that is full of problems. The limit introduced by the search for small visual clues-a billboard, public statuary, a faux pumpjack-is that one already knows the answer to the problem. The statistics tell us that Edmonton is a city whose economy is highly dependent on oil and so one goes looking for examples of oil iconography in its streets-and finds the results disappointing. The disappointment is two-fold: the (relative) absence of the kind of visible signs that one hoped to find; the lack of an appropriate index of a practice whose import suggests that one should find signs of it here, there and everywhere. This is a disappointment founded on a series of flawed interpretive presumptions, which nevertheless force us to confront the question of how to interrogate an oil imaginary in the absence of perceptible images of oil-the equivalent to the space of Sekula's harbours and the traffic between them.

As with Sekula's interrogation of Ulsan, we have chosen to engage with oil by looking at the way in which a local, supposedly peripheral space is mapped into the circuits of globalization. Situated in the northeastern corner of the province, and linked by a single, treacherous highway to other ports of call, Fort McMurray, Alberta, is far from the dominant population centres of Canada. At the same, it lies at the heart of the country's twenty-first century economy. In an age that is thought to be defined by the operations of service economy and cognitive capitalism-a high tech age in which immaterial capitalism trumps the material variety- $40 \%$ of the value of Canadian exports consists of the commodity extracted from the oil sands that surround the region (Cooper). The financial canyons of Toronto are filled with cash the origins of which can be traced back to a northern community struggling with the challenges of isolation and ferocious growth, which together produce social and economic difficulties of a kind experienced nowhere else in the country, and, indeed, in few other places on earth.

The most familiar images from Fort McMurray are of the oil sands themselves. These images are inevitably aerial shots whose intent is to emphasize the sheer size and scale of those sites at which bitumen is extracted-a vast and destructive mining operation that requires surface vegetation to be shoved aside, and which leaves behind massive tailings 'ponds' and mountains of sulfur. With the exception of small vehicles that appear to be more like toy trucks than the genuine monstrosities they 


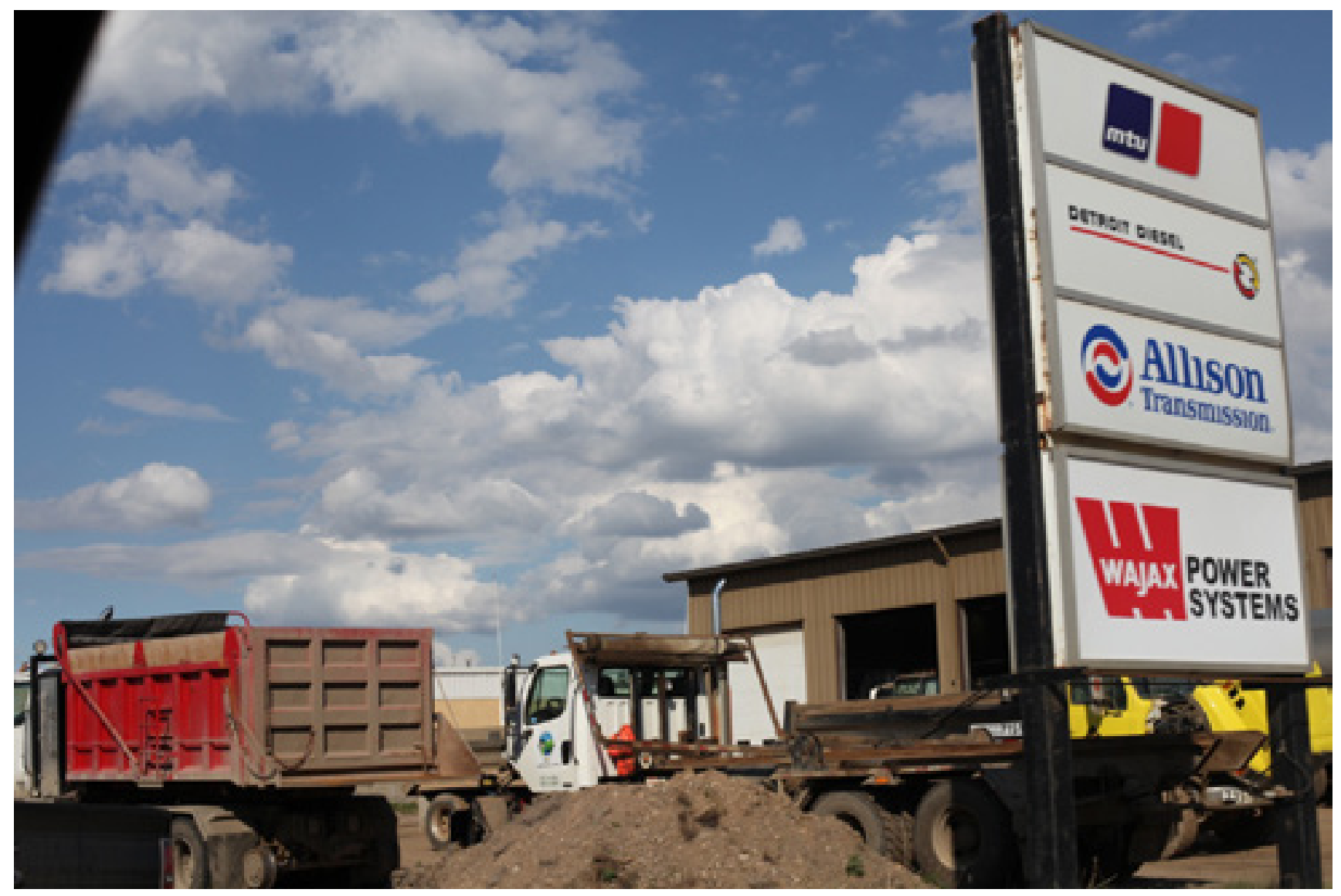

Fig. 4 Maria Whiteman, Power Systems

in fact are (the largest ground vehicles on the planet are put to work in the oil sands), there is seldom evidence of human bodies in action in the mine sites. To frame the scale of these sites in a single image is to say all that one needs to say about them: such images constitute not only a specific indictment of the oil sands, but form an allegory that condenses the brutal environmental consequences of capitalist modernity into a single image. Or such seems to be the presumption, based on visual representations of the oil sands to date.

We will leave aside the question of whether or not this scalar approach is ultimately successful, either aesthetically or politically. ${ }^{5}$ What we want to draw attention to is what is left out of such oil images: labour, forms of life, the experience of bodies working and living in proximity to the oil sands-in other words, all those varied registers of experience on which Sekula draws on to produce his critical photo-narratives of the shipping trade and its role in late capitalism. In a world replete with signs, images of the oil sands have limited themselves to the visualization of extraction sites; in doing so, they provide almost no account of the full complexity of the space and time called 'Fort McMurray.'

Let us be clear: by turning our attention away from mining sites, we intend no apologia for oil extraction 


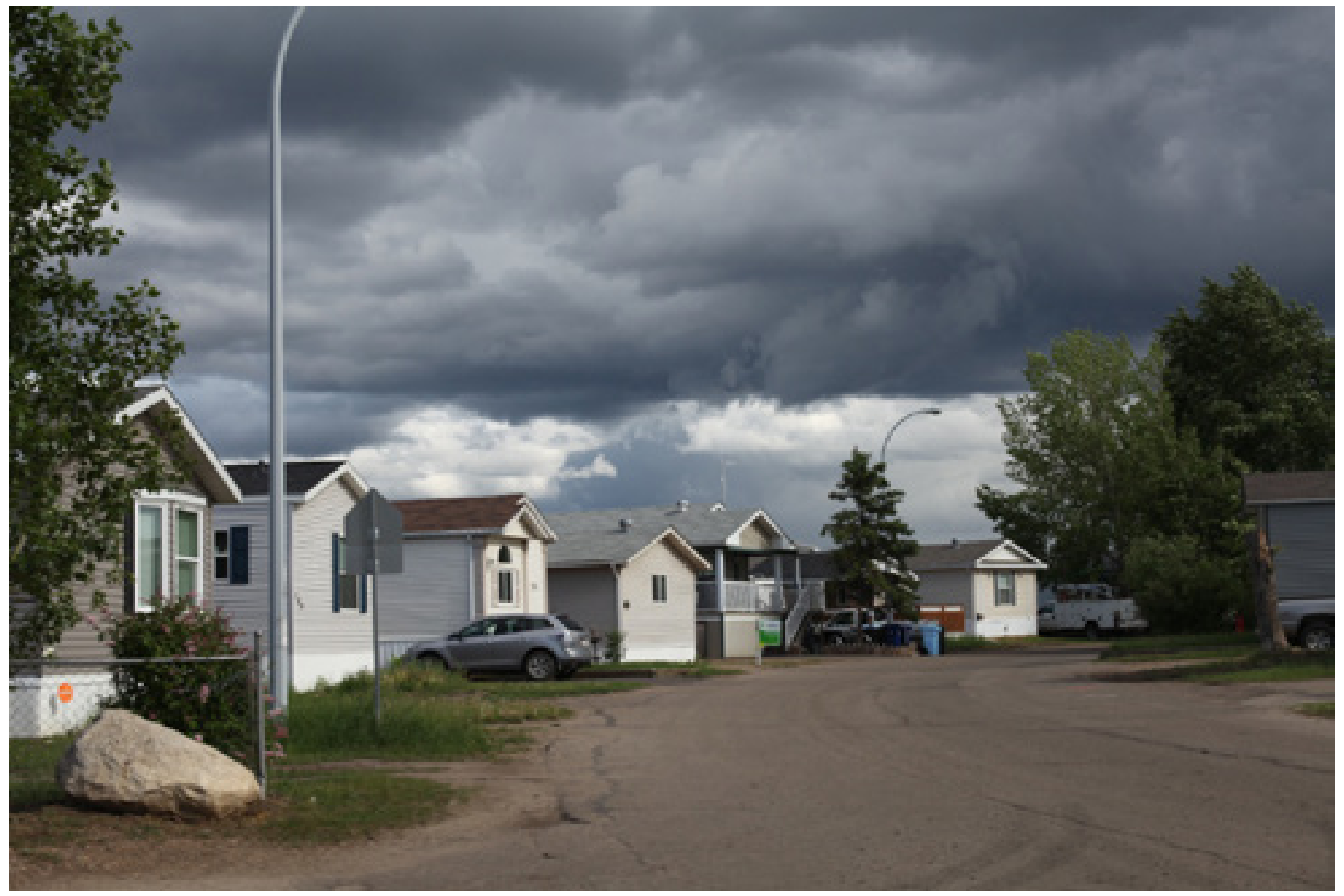

Fig. 5 Maria Whiteman, Gathering Storm

and its environmental consequences. On the contrary: we think it is only by more fully naming and explaining the dynamics of life and labour in relation to the sands that we can begin to figure the significance of a place that oil imaginaries in Canadian urban centres are so quick to render peripheral, assigning to it an environmental culpability which they somehow do not share. Paying attention to the signs of labour and globalization in Fort McMurray, to the organization of life and work at a central site of resource extraction on the planet, offers us a beginning point for a more complex and nuanced narrative of oil economies and their role in global capitalism.

\section{Recovery: Life, Labour, Oil-A Photo-Essay}

There is an incredible infrastructure needed to manage and enable work in the oil fields. In addition to the primary sites of oil extraction, workers are required to fill out a huge secondary economy made up of all manner service industries-from fast food and gas stations to firms specializing in the complex equipment required for oil exploration. With few notable exceptions, the oil extraction sites up north are hidden from view, accessible only via gated and guarded dirt roads. Much more visible - indeed, inescapable to vision-are the oil service companies, their vehicles, machinery, and the physical detritus that comes with infrastructure work. These 


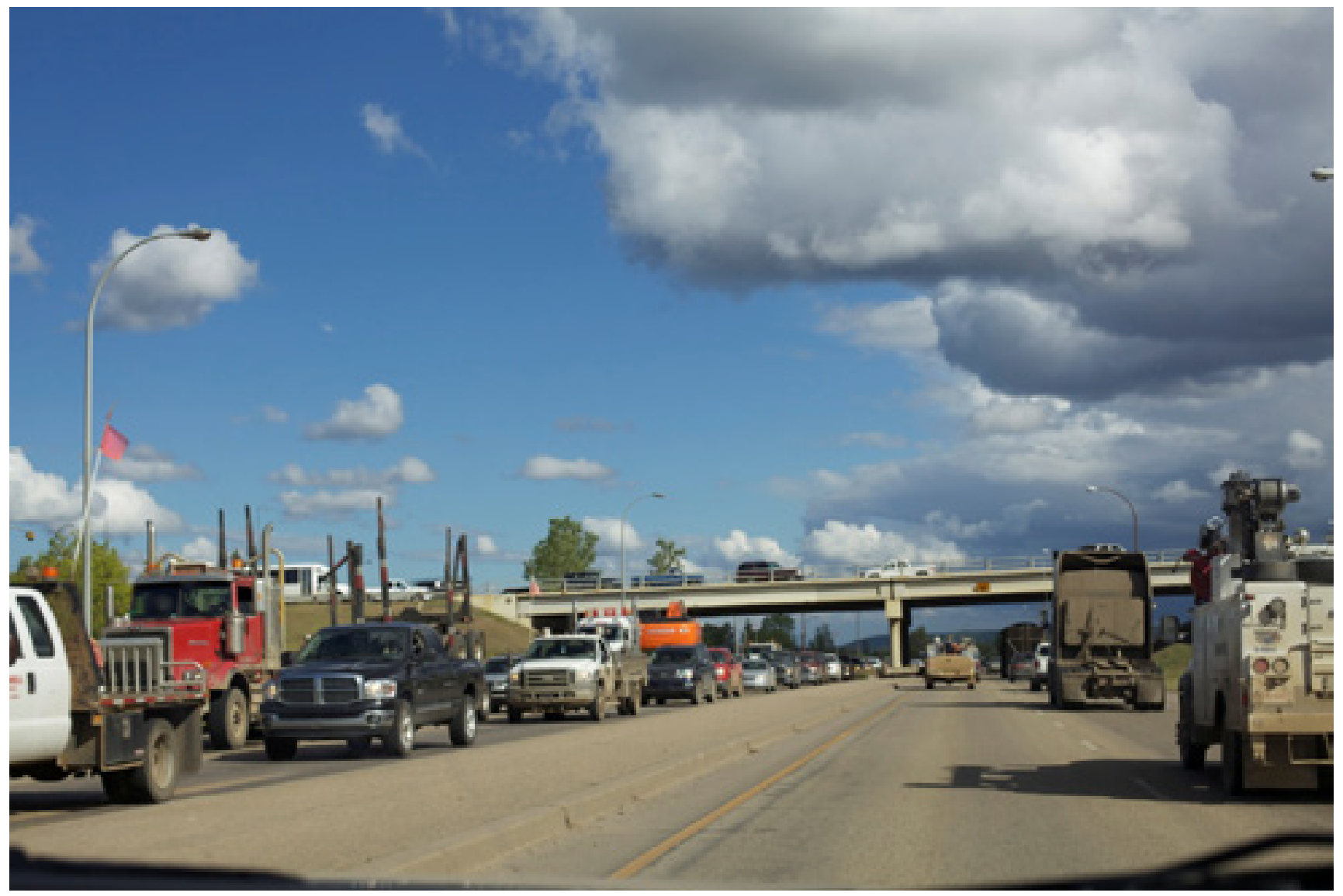

Fig. 6 Maria Whiteman, HWY 63 N \#1

companies occupy hastily constructed light industrial buildings on either side of the city; the strip malls that stretch between them contain bars, liquor stores, and those few companies in the city that can manage the high rents and uncertain economics of the place.

The workers who spend their days in these parts of Fort McMurray are perhaps the most heavily impacted by the high cost of living in the region. Well-paid, but not nearly as well compensated as the oil workers whose high salaries inflate the cost of housing, they must scramble to find a decent place to live. The lack of affordable housing (indeed the dearth of housing in any form) is due in part to the limited land made available for the development of private accommodation. The majority of the land surrounding the city is owned by the Crown, which has been slow in releasing it to the Municipality of Wood Buffalo- too slow to absorb the rapid expansion of population. ${ }^{6}$ As for the size of the population: a huge gap exists between municipal censuses and the ones conducted by the federal government, largely because the latter finds it hard to count the number of people living in unusual, quasi-legal dwellings across the region. The result: too few services for too many people, without even taking into consideration the large numbers of workers who spend chunks of time in Ft. 


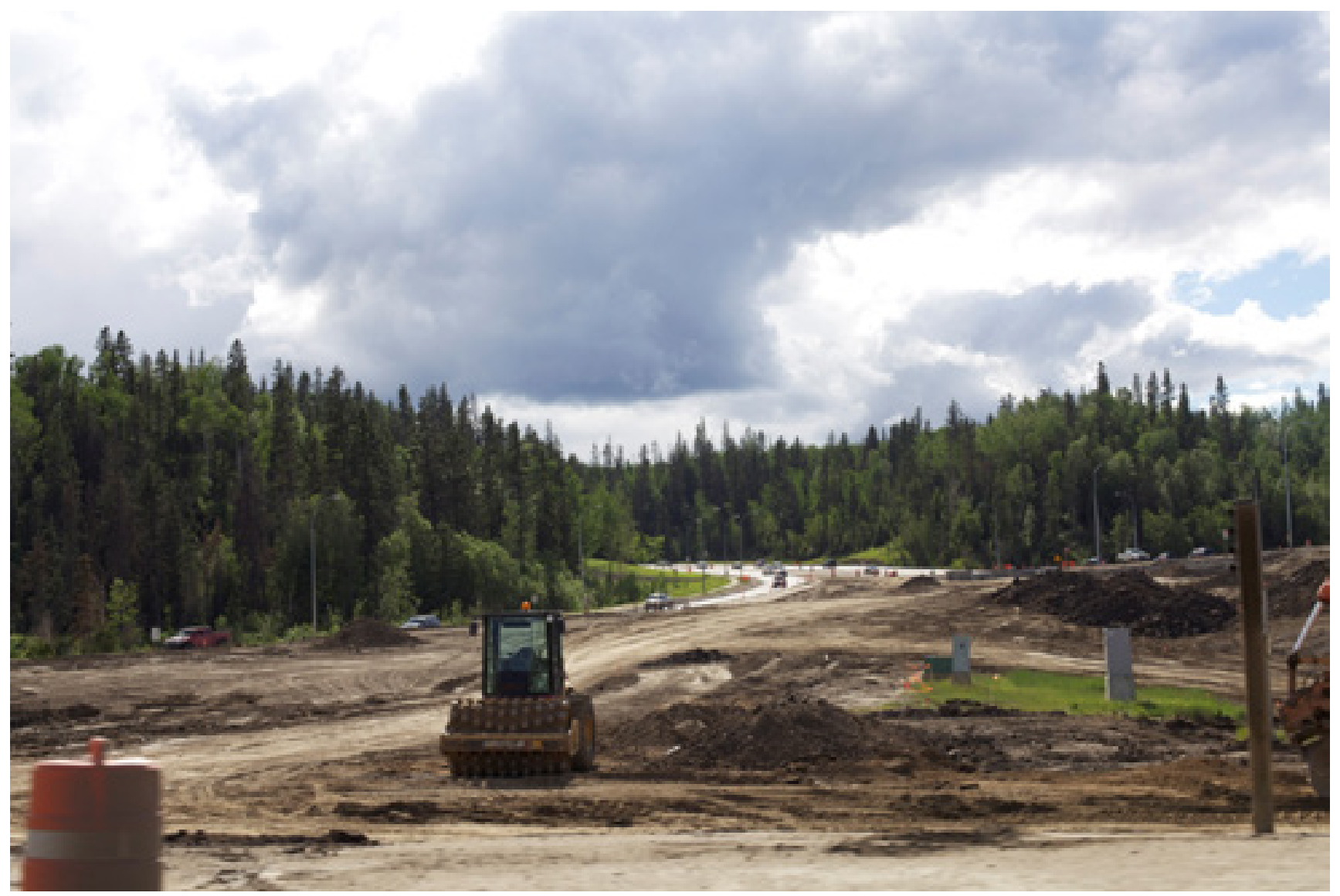

Fig. 7 Maria Whiteman, HWY 63 N \#2

Mac, flying in to work and out for breaks, who make demands on municipal services and extend the line-ups of the country's busiest Tim Hortons (Pratt).

New condo towers are being constructed in the city core, but for now, they remain sketches whose details have yet to be filled in. In other places, land is left unused by developers intent on driving up prices by producing and managing property scarcity. And so, on the outskirts of town, clumps of young men live in trailer homes, their new trucks squeezed together in the narrow driveways of their homes-away-from-home. It is hard to commit to a place where one must live in such conditions, which is no doubt why the city tends to feel ephemeral and impermanent, despite the ferocious activity in its streets.

The streets can be full of traffic. As with so much else (water and sewage systems, social services, etc.), there are more people living in the region than the architecture of the streets was designed to handle. At the beginning and the end of each workday, Highway 63 is jammed with traffic-a shock to a visitor or newcomer, who might expect the energies of commerce to run at a slower speed this far north. The city is in the midst of a massive expansion of road infrastructure. The bridge across the Athabasca River, which can already handle more 


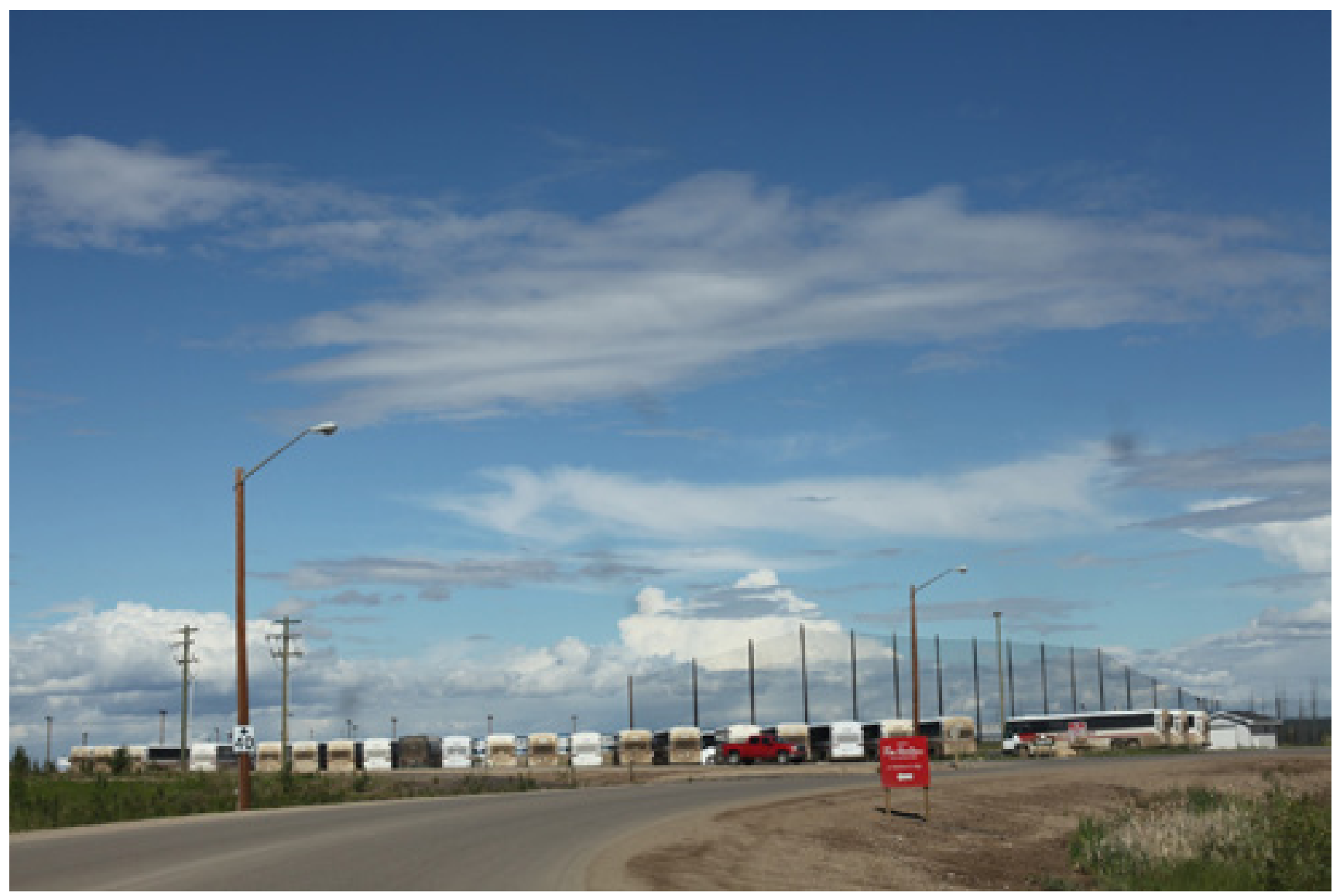

Fig. 8 Maria Whiteman, Transit

than three times the load of normal bridges in order to manage massive construction and transportation loads, is being widened and will eventually host ten lanes of traffic. Enormous new intersections, whose scale seems out of proportion with the size of the community it services, are being crafted to move traffic in and out of the huge suburbs nested in the boreal forest above the noise and chaos of the river valley.

Adding to the traffic: a fleet of mud-caked buses, which move workers from home to field, from field to airport, and from airport to work camp. On its 400 coaches and 300 site vehicles, the company Diversified records
5 million passenger trips a year. Even in a city whose economy depends on a substance linked to private car travel, mass transportation is a necessity. Much of the workforce arrives via plane to start their shifts at farflung mining and in situ sites. Without access to private cars, they are ferried by bus up and down 63, before snaking out on dirt and gravel roads whose sign posts bear the names not of nearby towns, but of extraction sites of specific companies: Suncor, CNRL, Shell.

In front of PTI's Athabasca and Wapasu Creek campsite $60 \mathrm{~km}$ north of the Ft. Mac, drivers pick up and unload workers in a scene reminiscent of a large city's 


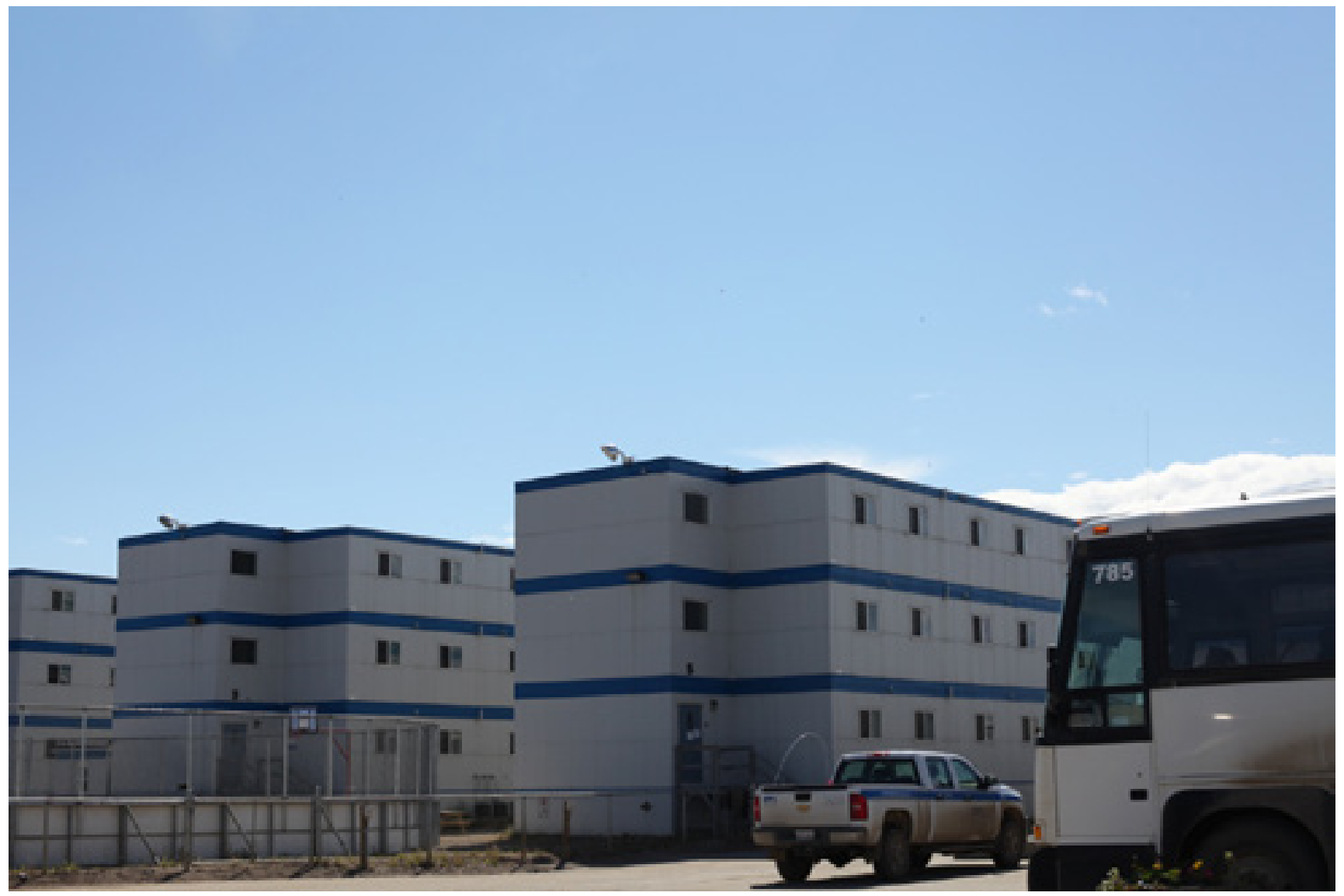

Fig. 9 Maria Whiteman, Camp \#1

central bus stop. Wearied workers stomp into the main entrance, grabbing a snack or coffee from the on-site Timmy's, before trudging off to their rooms. In the lobby, one can imagine that one is at one of the nicer chain hotels located off a highway ramp close to a big city. From the outside, however, the camp is lifeless, and resembles nothing if not a detention facility or prison. It comes as no surprise to learn that PTI built the military camps used by Canadian Forces in Afghanistan. The same disciplined, controlled, institutional logic pervades these buildings, up to the fact that many such camps are dry: no alcohol is allowed. In the rooms, workers are provided with Internet and satellite TV. Outside, the poorly constructed basketball court looks as if it has rarely been used; so, too, the golf driving range, which is dusty and empty of life. Camp life is time to be endured until the next spell away from work and back in civilization.

Recovery: what the body gets when it is away from Ft. Mac, but also the promise that everything will be replaced after industry has extracted what it needs. Whether recovery is in fact possible is hard to gauge from the few existing examples. A tour of the Suncor site ends with a trip through Wapisiw Lookout, a tailings pond that has been turned into a grassland dotted with 


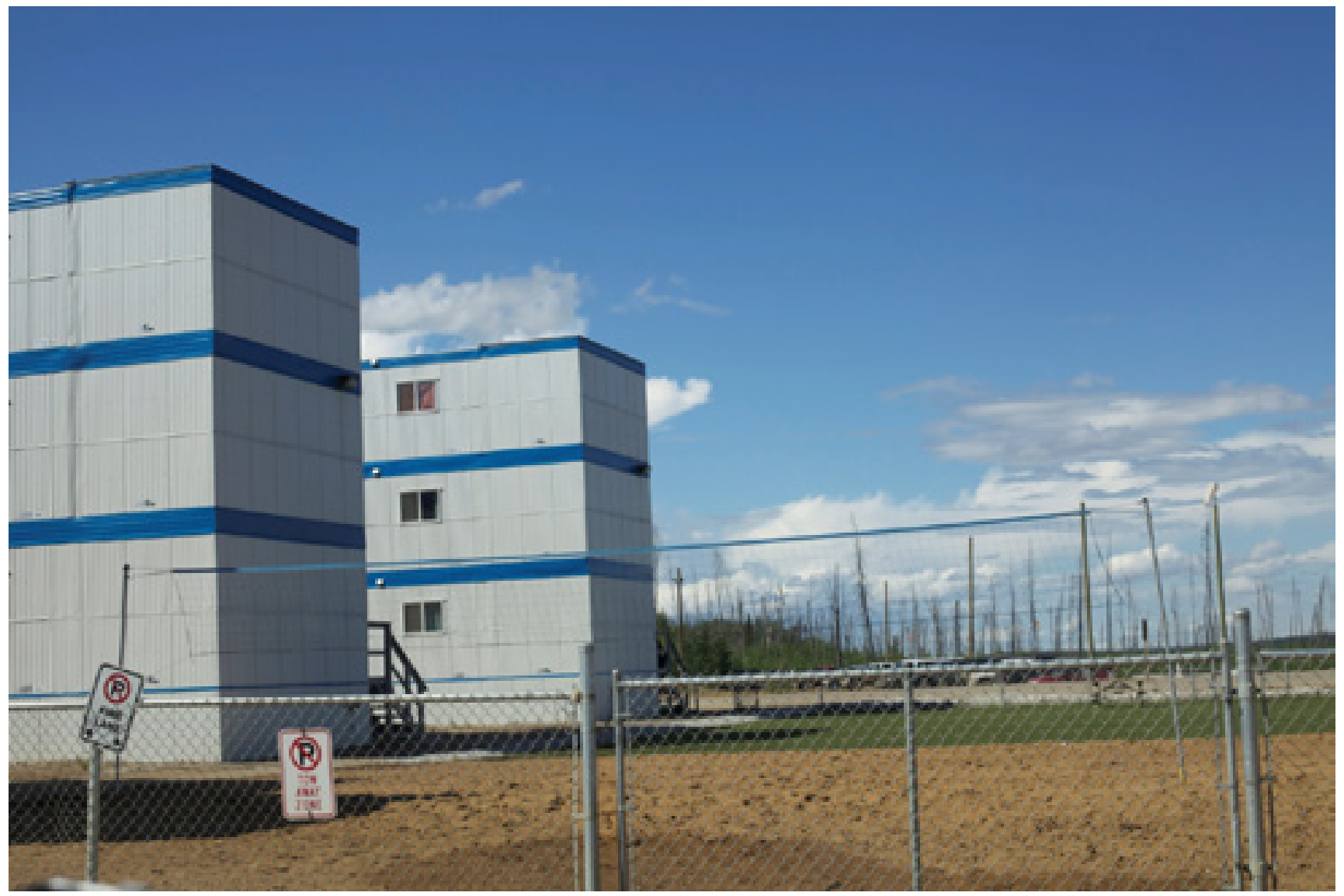

Fig. 10 Maria Whiteman, Camp \#2

clumps of rock for animal habitation and monitoring stations to measure the health of the soil under the grass. A video shown on the tour bus makes it clear that a great deal of science and effort was put into the task of reclaiming the site; to the eye, it looks unimpressive, incomplete, especially with the dunes of the Suncor site just behind it all too visible, regardless of which way one turns. A sign on the edge of the grassland reads: "Do Not Enter."

At the junction where Highway 63 loops back upon itself, one finds an earlier patch of reclaimed land: Syncrude's Gateway Hill. Across it run the Matcheetawin (the Cree word for "beginning place") Trails, at the head of which sits an installation representing the Cree circle of life. We walk the length of the trail and encounter no one. Indeed, the trail seems disused and forgotten: it is overgrown and many of the interpretive markers that identify reclamation dates and names of trees stuck back in are in danger of disappearing into the underbrush. Gateway Hill is experienced more as an object lesson of corporate responsibility whose message grows old fast, than as a space where one can spend time in nature. An industry pamphlet picked up at the Oil Sands Discovery Centre (printed on recycled paper) reads: "Canada's oil sands industry is committed to reducing its footprint, reclaiming all land affected by operations and maintaining biodiversity" (CAPP n.p.). Even if one were 


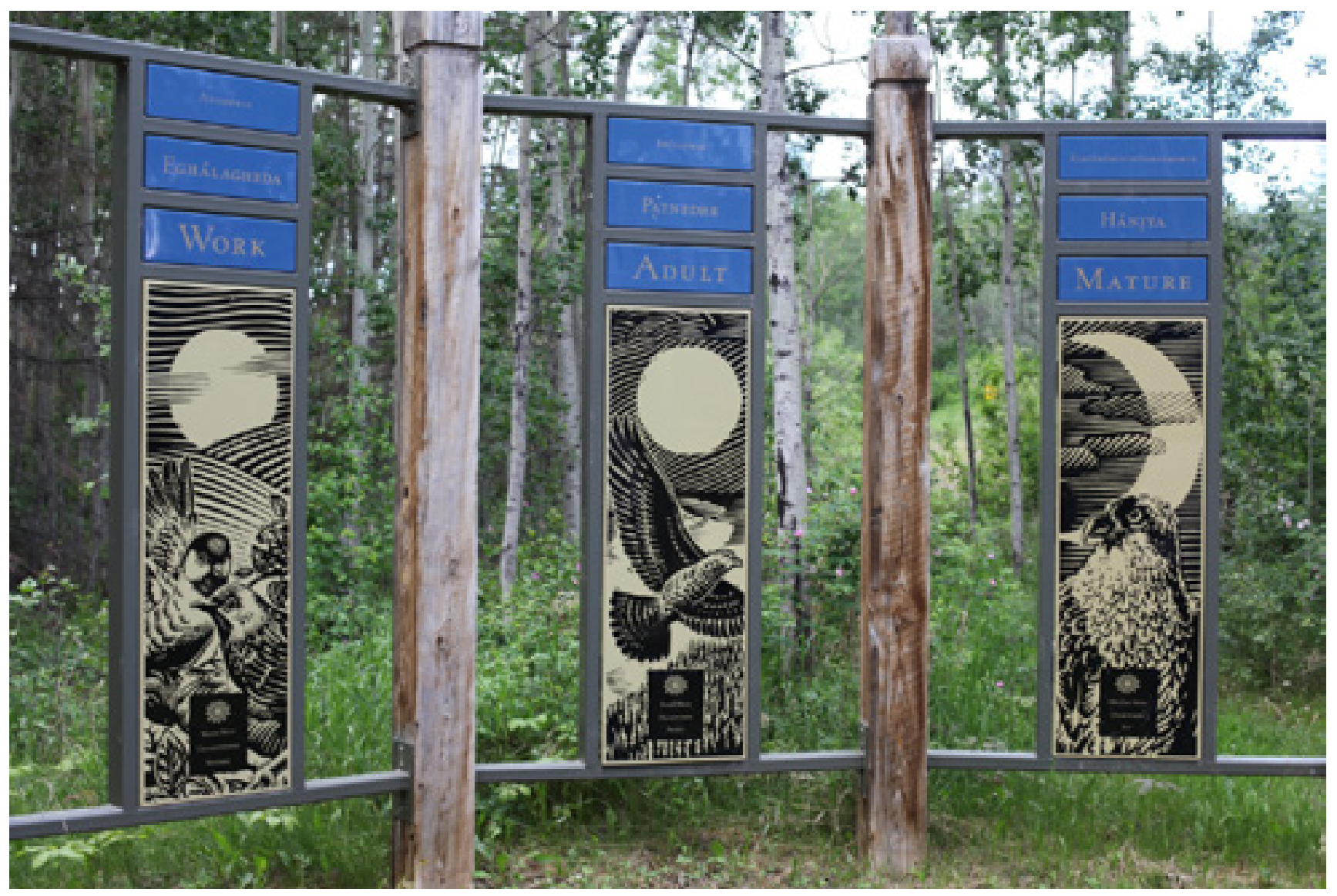

Fig. 11 Maria Whiteman, Work Adult Mature

not to doubt the commitment, the existing evidence of the recovery suggests that the industrial use of the land will leave permanent scars, both on nature and on those who will live alongside these spaces.

At the Suncor Community Leisure Centre, people lift weights, make use of the jogging track, enjoy the pool and read in the community library. On the day we visit, the indoor soccer courts are taken up with events connected to the 32nd Annual Alberta Surface Mine Rescue Competition. This is the only sign that we are someplace strange-the only burst to the surface of consciousness of an economy that elsewhere is able to all too easily hide in the nooks and crannies of daily life and habit.
It is tempting to see Fort McMurray as exceptional. But even a brief encounter with this place makes it clear that it should be seen as an index of the rule of life and labour in the $21^{\text {st }}$ century. As long as we treat it as an exception, we avoid reading in its configurations the signs of our own crises, conveniently shedding our culpability in the environmental and social circumstances generated by the oil sands. Is it not the case that, in effect, we all live next to sites of oil extraction, even if it is all too easy for many of us to offshore this recognition to remote sites, whether at home or abroad? Do we not all participate in an oil economy? Are we not all agents of a capitalism run amuck, which has so diminished social life that we live in our homes as if in a work camp-waiting for the 


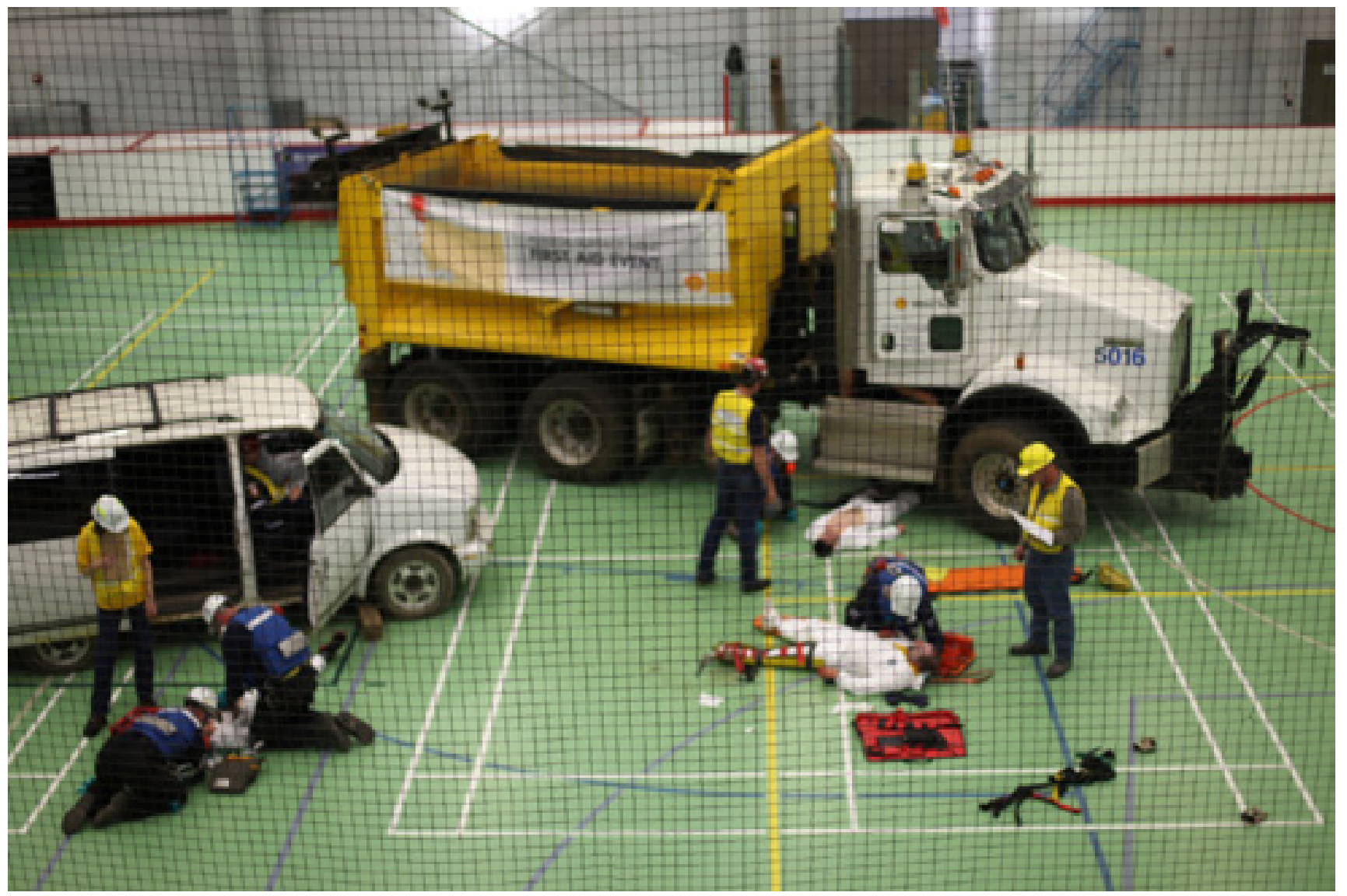

Fig. 12 Maria Whiteman, First Aid

moment to come when we finally are off work for good and don't have to spend our days in thrall to the private solitude of satellite TV?

By using photographs to open up an investigation of the material realities of globalization, Sekula's practice of critical realism has offered a counterpoint to those discourses that too quickly narrate the global present through the ephemerality of telecommunications systems and the near instantaneity of the movement of ideas, money, and even bodies. Sekula's Fish Story emphasizes the sites where multiple forms of exchange take place-the harbours and docks-as well as the slowness of physical movement in a world whose contemporary substance is most often given form through narratives of speed. We believe that engaging in a critical realist photo practice in relation to oil produces similar insights into both the narratives that surround it and the role this substance plays in giving shape to global reality. Oil is an omnipresent feature of the world we inhabit-the life-giving substance of the physical and imaginary infrastructures we have shaped over the past century-and-a-half. Even so, there is a tendency to ignore or to underplay its significance, seeing it instead as an important but not irreplaceable substance, as one form of energy which can eventually be substituted for others without necessitating major changes in social life. Our focus on Fort McMurray is 
meant to give shape, depth and complexity to a place that has become little more than a normative by-word for all that is wrong with the world. As with Sekula's visual-textual interrogations, critical realism of the oil sands also generates more general reflections on the narrative forms through which globalization is named and explained, and draws attention to the real bodies and the living labour that continues to be put to use to generate profit regardless of the consequences.

\section{Image Notes}

Fig. 1 Maria Whiteman, HWY 63 N \#3

Fig. 2 Maria Whiteman, Dune (2012)

Fig. 3 Imre Szeman, Pumpjack (2012)

Fig. 4 Maria Whiteman, Power Systems (2012)

Fig. 5 Maria Whiteman, Gathering Storm (2012)

Fig. 6 Maria Whiteman, HWY 63 N\#1 (2012)

Fig. 7 Maria Whiteman, HWY 63 N \#2 (2012)

Fig. 8 Maria Whiteman, Transit (2012)

Fig. 9 Maria Whiteman, Camp \#1 (2012)

Fig. 10 Maria Whiteman, Camp \#2 (2012)

Fig. 11 Maria Whiteman, Work Adult Mature (2012)

Fig. 12 Maria Whiteman, First Aid (2012)

\section{Works Cited}

Appadurai, Arjun. Modernity at Large: Cultural Dimensions of Globalization. Minnesota: U of Minnesota P, 1996. Print.

Baetens, Jan and Hilde Van Gelder, eds. Critical Realism in Contemporary Art: Around Allan Sekula's Photography. Ithaca, NY: Cornell University Press, 2010. Print.
Ernst Bloch et. al. Aesthetics and Politics: They Key Texts of the Classic Debate Within German Marxism. New York: Verso, 1977. Print.

Buchloh, Benjamin. "Allan Sekula: Photography Between Discourse and Document" in Allan Sekula, Fish Story. Dusseldorf: Richter Verlag, 1991. 189200. Print.

Canadian Association of Petroleum Producers (CAPP). Upstream Dialogue: The Facts on: Oil Sands. April 2012. Print.

Cooper, Dave. "West Coast pipeline key to Canada's interests, economist says." Edmonton Journal. 10 May 2012: C1. Print.

Dirlik, Arif. "The Global in the Local." Global/ Local: Cultural Production and the Transnational Imaginary. Eds. Rob Wilson and Wimal Dissanayake. New York: Columbia UP, 1994: 21-45. Print.

Fredric Jameson, "Beyond the Cave: Demystifying the Ideology of Modernism." The Bulletin of the Midwest Modern Language Association 8.1 (1975): 1-20. Print.

--. “Modernism and Imperialism." Nationalism, Colonialism, and Literature. Minneapolis: U of Minnesota Press, 1990. 43-66. Print.

--. Postmodernism, or, The Cultural Logic of Late Capitalism. Durham, N.C.: Duke UP, 1991. Print.

Morton, Timothy. Ecology Without Nature: Rethinking Environmental Aesthetics. US: Presidents and Fellows of Harvard College. 2007. Print.

Regional Municipality of Wood Buffalo. "Cost of Living." Web.

Pratt, Sheila. "Federal Census Missed Thousands of Residents, Fort McMurray's Mayor Says." Edmonton Journal. Feb. 8, 2012. Web. Aug. 6, 2012. 
Sekula, Alan. Fish Story. Dusseldorf: Richter Verlag, 1991. Print.

---. Photography Against the Grain: Essays and Photoworks 1973-1983. Ed. Benjamin Buchloh. Halifax: The Press of the Nova Scotia College of Art and Design, 1984. Print.

Szeman, Imre. "Crude Aesthetics: The Politics of Oil Documentaries." Journal of American Studies 46.2 (2012): 423-439. Print.

Szeman, Imre and Maria Whiteman. "The Big Picture: On the Politics of Contemporary Photography." Third Text 23.5 (2009): 551-556. Print.

\section{(Endnotes)}

1. The one sustained confrontation with Sekula's critical realism can be found in, a collection of papers from a symposium held at the Lieven Gevaert Research Centre for Photography and Visual Studies (Belgium) in September 2005.

2. See the essays in Bloch et. al. and Fredric Jameson's essay "Beyond the Cave: Demystifying the Ideology of Modernism."

3. Other art photographers identified with realism use it to different effect through the size of the photos in their exhibitions and the scale their images represent. For a discussion of this form of realism, see Imre Szeman and Maria Whiteman, "The Big Picture: On the Politics of Contemporary Photography."

4. Against the comforts of capacity, we follow Timothy Morton's response to the habit of the "beautiful soul" to remain in cynicism. He writes:

Our choice is false if it has been reduced to one between hypocrisy and cynicism, between wholeheartedly getting into environmental rhetoric and cynically distancing ourselves from it. In both cases, we would be writing liturgies for the beautiful soul. Although it is 'realistic' to be cynical rather than hypocritical, we do not wish to reinforce the current state of affairs. Our answer to the ruthless ransacking of nature, and of the idea of nature, must be yes, we admit to the reality of the situation. And no, we refuse to submit to it. (140)

5. For an extended discussion of the politics of scale in environmental film, see Imre Szeman, "Crude Aesthetics: The Politics of Oil Documentaries," especially 432-439.

6. "The main service area of Fort McMurray is surrounded by Crown land and therefore, there is limited land available for development where most people live" (Regional Municipality of Wood Buffalo). 
Szeman Imre: Imre Szeman is Canada Research Chair in Cultural Studies and Professor of English and Film Studies at the University of Alberta. He is the author, coauthor or co-editor of ten books to date; four additional books are under contract and will appear in print by 2014. As author or co-author, he has written Zones of Instability: Literature, Postcolonialism and the Nation (2003), Popular Culture: A User's Guide (2003, 2nd ed.2009,3rded.2013, co-written with Susie O'Brien), and After Globalization (2011, co-written with Eric Cazdyn). His editorial projects include Pierre Bourdieu: Fieldwork in Culture (2000), The Johns Hopkins Guide to Literary Theory and Criticism (2004), Canadian Cultural Studies: A Reader (2009), Global-Local Consumption (2010), Cultural Autonomy: Frictions and Connections (2010), Cultural Theory: An Anthology (Blackwell, 2010), and most recently, Contemporary Literary and Cultural Theory: The Johns Hopkins Guide (2012).

Szeman, Imre : Imre Szeman est titulaire d'une chaire de rechercheduCanada enétudesculturelles, et est professeur d'anglais et d'études cinématographiques à l'Université de l'Alberta. Il est auteur, co-auteur et coéditeur d'une dizaine de livres à ce jour -quatre autres livres étant sous contrat et devant paraître d'ici 2014. Parmi ses œuvres, on trouve : Zones of Instability: Literature, Postcolonialism and the Nation (2003), Popular Culture: A User's Guide (2003, $2^{\text {ème }}$ ed. 2009, $3^{\text {ème }}$ ed. 2013, coauteure : Susie O'Brien), et After Globalization (2011, co-auteur : Eric Cazdyn). Parmi ses travaux éditoriaux, on trouve : Pierre Bourdieu: Fieldwork in Culture (2000), The Johns Hopkins Guide to Literary Theory and Criticism (2004), Canadian Cultural Studies: A Reader (2009), Global-Local Consumption (2010), Cultural Autonomy: Frictions and Connections (2010), Cultural Theory: An Anthology (Blackwell, 2010), ainsi que Contemporary Literary and Cultural Theory: The Johns Hopkins Guide (2012).
Whiteman, Maria: Maria Whiteman is Assistant Professor of Drawing and Intermedia in Fine Arts at the University of Alberta. She teaches courses in mixed media, photography, video, drawing and installation art. Her current art practice explores themes such as art and science, relationships between industry, community and nature, and the place of animals in our cultural and social imaginary. In addition to her studio work, she conducts research in contemporary art theory and visual culture. She is currently working on The Retreat (coeditor; to be published by Autonomedia) and Refiguring the Animal: Plasticity and Contemporary Art (co-edited with Amanda Boetzkes; to be published by University of Minnesota Press). In 2011, Whiteman had a solo exhibition at Latitude 53 and she will be included in the 2013 Alberta Biennial at the Art Gallery of Alberta. Whiteman is a co-director of the 2012 Banff Research in Culture/documenta 13 research residency.

Whiteman, Maria : Maria Whiteman est professeure adjointe de dessin et de recherches intermédiatiques dans la branche des Beaux-Arts à l'Université de l'Alberta. Elle enseigne des cours sur les médias mixtes, la photographie, la vidéo, le dessin, et l'art de l'installation. Son projet artistique actuel consiste en l'examen de thèmes comme l'art et les sciences, les rapports entre l'industrie, la communauté et la nature, et l'importance des animaux dans les imaginaires culturel et social. En plus de son travail en studio, elle mène des recherches théoriques en art contemporain et en culture visuelle. Elle est coéditeure de The Retreat (Autonomedia, à paraitre) et de Refiguring the Animal: Plasticity and Contemporary Art (University of Minnesota Press, à paraître; coéditeure : Amanda Boetzkes).

Copyright Imre Szeman and Maria Whiteman. This article is licensed under a Creative Commons 3.0 License although certain works referenced herein may be separately licensed, or the author has exercised their right to fair dealing under the Canadian Copyright Act.

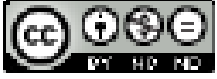

